\title{
LAW ENFORCEMENT BASED ON THE ENVIRONMENT: SOLUTION OF LAND PROBLEMS AFTER TSUNAMI, LIQUEFACTION, AND EARTHQUAKE IN CENTRAL SULAWESI
}

\author{
Sulbadana \\ Faculty of Law, Universitas Tadulako, Palu \\ sulbadana@untad.ac.id
}

\begin{abstract}
On September 28, 2018, there was a natural disaster in the form of Tsunami, Liquefaction, and Earthquake that struck Palu City. Sigi Regency and Donggala Regency, Central Sulawesi Province, in addition to damaging various infrastructures, the natural disaster also claimed lives that made the government have to issue a policy by setting red zones or areas that are not habitable. With the policy to determine the red zone, it will certainly cause problems related to the status of the land after being abandoned by the owner and until now there is no certainty related to what is the basis for the determination of the red zone by the government, there is no guarantee that the red zone is an uninhabitable area, giving rise to a polemic what if after being abandoned for a long time it turns out that nothing happened as feared in the red zone. The law is demanded to be present to answer the problem and provide solutions for all parties with a legal approach based on ecology and the values of natural balance.
\end{abstract}

Keywords: Red Zone; Natural Disaster; Ecology Based Laws

\section{Introduction}

A disaster is an event or series of events caused by nature and/or humans, resulting in human casualties, property losses, damage to facilities or infrastructure, environment, public facilities, loss of sources of life, and loss of access to sources of life. Indonesia ranks second as the country most frequently hit by disasters with 71 events or nearly $9 \%$ of the total number of disasters in the world. The reason why Indonesia is ranked second is because of Indonesia's geographical location which is at the confluence of the three main plates forming the Earth's crust, namely the Eurasian Plate which moves southeast and the Indo-Australian Plate which moves extends across the Indian Ocean from the north (Aceh) to around the Sea Timor in the east and the Pacific Plate that moves around the Pacific Ocean to the north of Papua. ${ }^{1}$ Contemporary, there is a need for action environmental protection due to its constant changes. ${ }^{2}$

According to ISDR 2004 (International Strategy for Disaster Reduction), institutions under the United Nations mean that disaster is a serious disruption to the functioning of a society,

\footnotetext{
Rahmat Aris ; Iwan Rudiarto Pramoto, "Tsunami Modeling and Its Implications for Disaster Mitigation in Palu City," Jurnal Pembangunan Wlayah dan Kota, Biro Penerbit Planologi Undip (2013): 37-49.

2 Jean Claude Geofrey Mahoro, "ICAO'S Role In Environmental Protection And Its Shortcomings Under Rapid Growth Of Aviation Industry," Diponegoro Law Review 4, no. 2 (2019): 3-15.
} 
causing widespread harm to human life in terms of material, economic or environmental aspects and beyond the ability of the community concerned to cope with using their resources. ${ }^{3}$ In-Law Number 24 of 2007 concerning disaster management, a disaster is defined as an event or series of events that threaten and disrupt people's lives and livelihoods caused, both from natural and/or non-natural factors as well as human factors, resulting in human casualties, environmental damage, property loss, and psychological impact.

Invaluable experience and knowledge of such disasters are held almost uniquely at a local level reflecting the ways that local people confront diverse, context-specific, small-scale, unpublicized "everyday disasters" alongside better-publicized intensive events. Such eventsoften configured by dynamically changing social, political, economic and environmental conditions-underwrite the increasing importance of sharing knowledge between local and nonlocal stakeholders to better understand and address existing and new challenges for a safer and sustainable future. At the same time, relatively little learning and knowledge sharing is generated amongst local-level practitioners and communities who are typically activists and have limited opportunities to reflect, think critically, capture and record learning or share it peer to peer. ${ }^{4}$

On September 28, 2018, an event that shocked the world occurred in Palu City, Donggala Regency, and Sigi Regency in Central Sulawesi, where several natural disasters occurred at one time, namely earthquake, tsunami, and liquefaction. The natural disaster caused the capital of Central Sulawesi Province to become paralyzed and have an impact on all surrounding districts even in Pasangkayu Regency, West Sulawesi Province. The number of fatalities due to the earthquake and tsunami reached 1,763 people. Of these, as many as 1,519 bodies were found in Palu. Meanwhile, as many as 159 bodies were found in Donggala. In Sigi, 69 fatalities were found; 15 bodies in Parigi and 1 body were found in Pasangkayu, according to BNPB, the most fatalities were found in Palu City. The number of fatalities due to the earthquake and tsunami reached 1,763 people. Of these, as many as 1,519 bodies were found in Palu. Meanwhile, as many as 159 bodies were found in Donggala. In Sigi, 69 fatalities were found; 15 bodies in Parigi and 1 body were found in Pasangkayu, according to BNPB, the most fatalities were found in Palu City.

Nandian Mareta, Disaster Knowledge and Management NMST (Jakarta: LIPI, 2014).

John and Terry David Gibson Norton, "Introduction to Disaster Prevention: Doing It Differently by Rethinking Thenature of Knowledge and Learning," Disaster Prevention and Management (2019): 47-60. 


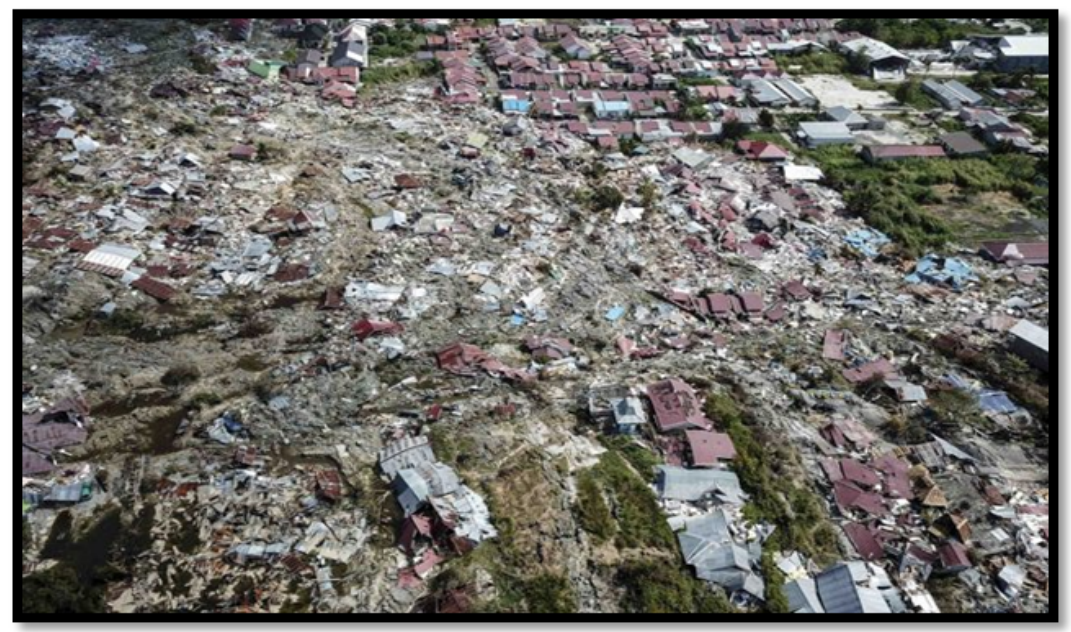

Figure 1. Damage due to the Palu earthquake in the Petobo Region ${ }^{5}$

BNPB said 66,926 houses were damaged by the Palu earthquake and tsunami in Central Sulawesi. Damaged houses in Central Sulawesi totaled 66,238 units. Whereas in the area of West Sulawesi which was also affected by the number of damaged houses 688 units. In West Sulawesi houses were severely damaged 250 units, moderately damaged 223 units, and 215 units slightly damaged. the Palu earthquake and tsunami caused 2,736 schools to be damaged and seven health facilities to be severely damaged. the damaged facilities were Anutapura Hospital and six puskesmas namely Talise, Bulili, Mamboro, Lere, Nosara, and Singgani Puskesmas. damaged houses and buildings were mostly in areas badly affected during the earthquake and tsunami. One of them is in Balaroa, Palu. The estimated number of buildings damaged was 1,045 units, the total area affected was 47.8 hectares. Another area that has many damaged buildings is in Petobo, Palu. Petobo was an area that was affected by the faction during the Palu earthquake which caused the area to be covered by 180 hectares of mud. Estimated buildings affected in Petobo totaled 2,050 units. ${ }^{6}$

\footnotetext{
5 BNPB Provinsi Sulawesi Tengah, "Kerusakan Akibat Gempa Palu Di Wilayah Petobo," BNPB Provinsi Sulawesi Tengah.

6 BNPB Provinsi Sulawesi Tengah, “Gempa Dan Tsunami Palu Merusak 66926 Rumah,” Tempo.
} 


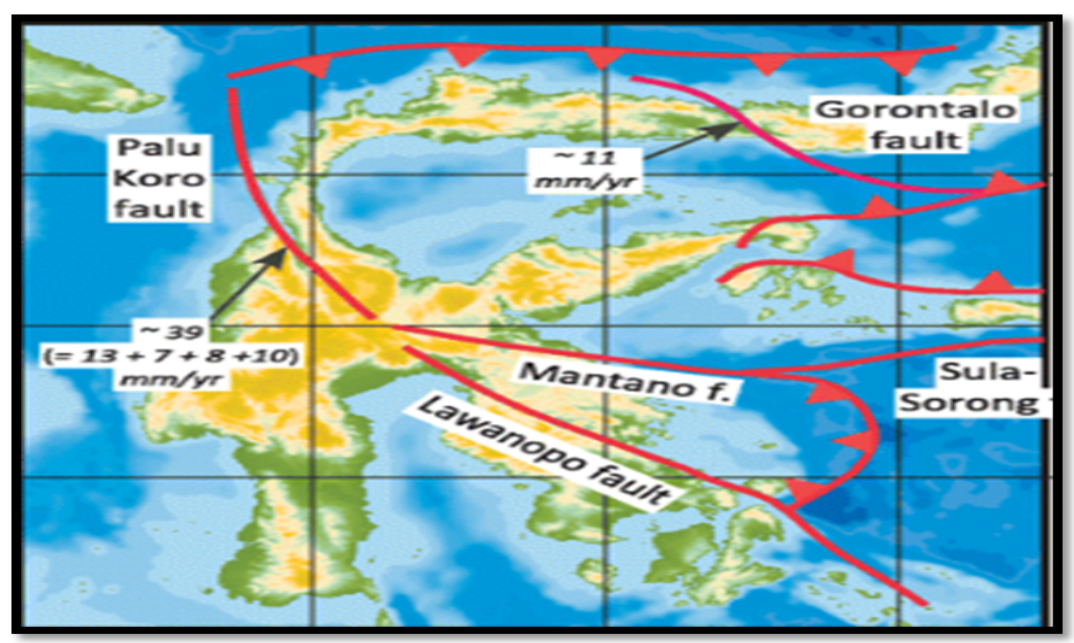

Figure 2. Location of the Koro Palu Fault ${ }^{7}$

The city of Palu has an active Palu-Koro fault that should not have built houses or infrastructure, as part of the disaster mitigation measure, the government-appointed BIG to map disaster-prone areas in alternative cities to become the capital of Central Sulawesi. The government is also said to be planning to relocate residents of Palu to get out of the fault line. In terms of geographical aspects, the head of the BIG disaster and climate change mapping field, said that Palu is certain to be a disaster-prone point such as earthquakes, tsunamis, landslides. Palu-Koro is the most active fault in Indonesia. Its strength even reaches three times compared to other fault movements so that it is certain that earthquakes can occur, many infrastructures built on fault lines also have a severe impact during disasters. The shape of the Palu strait known as a closed canal can also amplify the tsunami's impact. ${ }^{8}$

In addition to swallowing fatalities, the natural disaster also raises legal issues including debit/credit issues, then Zoning stipulations that result in the determination of habitable areas will certainly cause loss of rights for communities whose areas are designated as red zones and are not livable. The Deputy for Geospatial Information, Geospatial Information Agency (BIG) stated that the city of Palu is categorized as unfit to be a city in Central Sulawesi. The city of Palu is considered a 'disaster subscription' with a geographical location traversed by four active faults and is surrounded by plates. The statement was also based on the results of an in-depth

BNPB Provinsi Sulawesi Tengah, "Kerusakan Akibat Gempa Palu Di Wilayah Petobo.”

8 CNN Indonesia, "Peneliti: Palu Langganan Bencana Tak Layak Jadi Kota," CNN Indonesia (Jakarta, November 2019). 
study which showed that Palu was not fit to be a city. Following on the picture can be seen zoning.

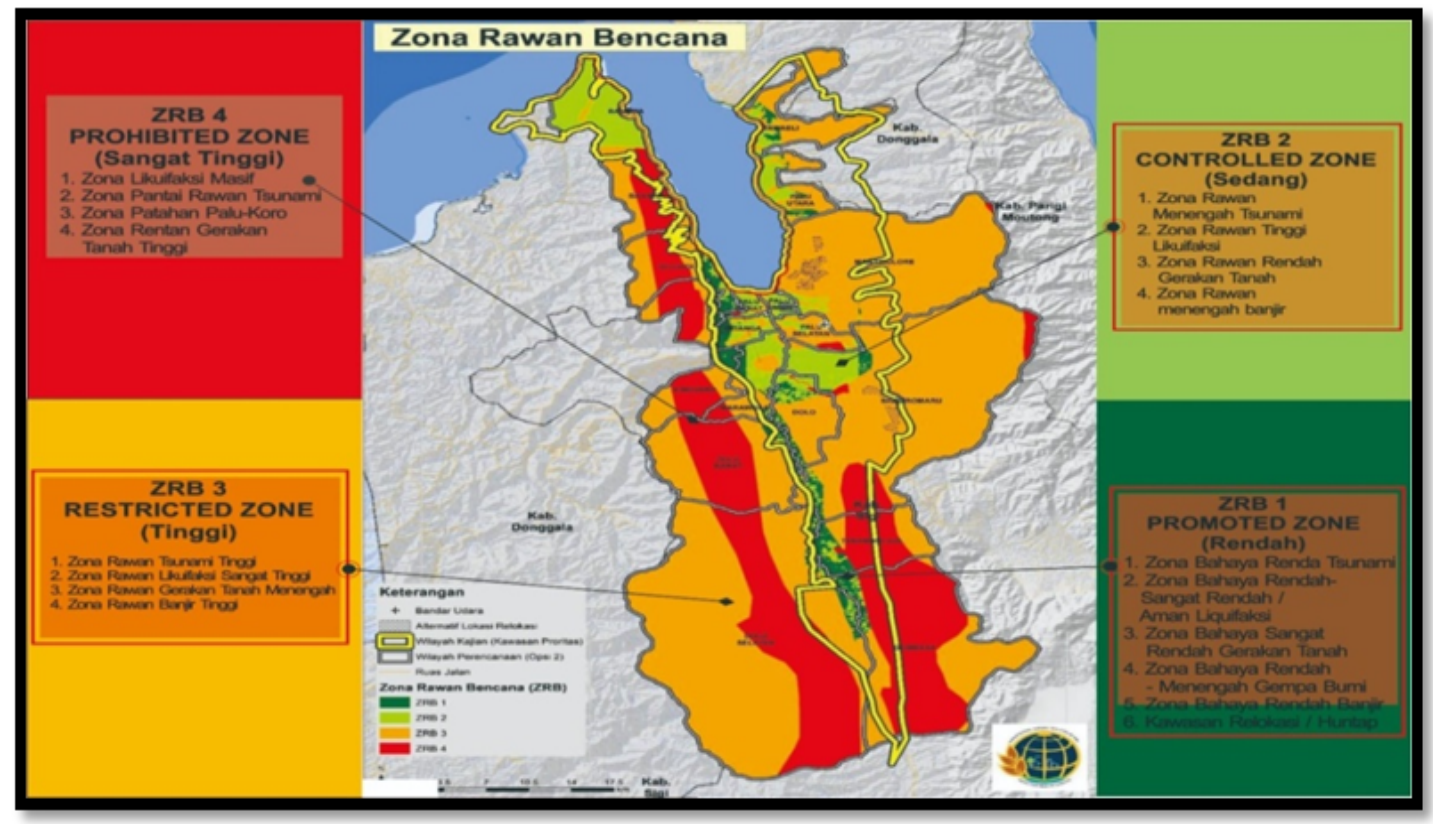

Figure 3. Disaster-Prone Zone ${ }^{9}$

Based on the background, the problem raised in this paper is how is the concept of ecology-based law in resolving post-disaster land status problems in Palu City?

\section{Methods}

This study is normative juridical research, dissecting issues formulated through laws and regulations and the concept based on the environmental law. This study is carried out by using a doctrinal approach, which prioritizes a philosophical and juridical approach.

\section{Results and Discussion}

\subsection{The Correlation between Humans and the Environment Views of Religious Wisdom}

Nature was indeed created by God for humans (Al Qur'an, 2: 38), including all its resources either buried deep in the ground, at sea, in the air or that lie on the surface of the earth (Al Qur'an 16 : 5-14; Al Qur'an 57 :25), It is a human right to utilize all of these resources, but he must also remember that in addition to meeting the needs of his life, nature was created by God as a form

9 BNPB Provinsi Sulawesi Tengah, "Kerusakan Akibat Gempa Palu Di Wilayah Petobo.” 
of learning with which people will know God better. Disasters will have adverse impacts on various fields of community life. In addition to material losses, moral losses that arise are mental conditions that decline or are disrupted because people lose property and families due to disasters. ${ }^{10}$ To lessen the catastrophic impacts of disasters on people, assets and the environment, governments, scholarships and international agencies are increasingly focusing on strategies for reducing and adapting to disaster risks. ${ }^{11}$

The holy books of Islam, Christianity, and Judaism have recorded many environmental problems faced by humans. The flood that was faced by Noah, or various difficulties experienced by Prophet Musa in the mountains of sand during his wandering in Egypt to Cana, are examples of environmental problems. ${ }^{12}$ An event that befell oneself can be concluded as a result of various influences around it. So many influences that push people into a certain situation, so it is natural that humans then try to understand what affects themselves and to what extent these influences. ${ }^{13}$

The environment is an absolute part of every human life. Humans breathe, get light (light) because there are air and sun. Likewise, human needs to find food, drink, make a house, and take shelter is also the acquisition of the environment. So, the presence of the environment is very important and crucial for the presence and survival of human beings, for their culture and civilization. Or in other words, environmental factors are an inseparable part for humans. ${ }^{14}$

The verses in the Qur'an often even sometimes mention warnings to humans to always protect the environment and preserve the environment. Do not let humans make damage on earth so that the impacts that occur disturb the stability of the environment.

\subsection{Earth Transformation Towards Equilibrium in Theological Environmental Law Concepts.}

With regard to environmental preservation, religions are expected to be able to answer the question of human relations and the environment, the arguments explain about the environment and religious values that can encourage the effectiveness of environmental ethics ${ }^{15}$. Mary E. T. dan John A. G. argues that "no religious tradition or philosophical perspective has an ideal (best)

10 Wiwik Sulistyaningsih, "Ketangguhan Mental Anak Dalam Menghadapi Bencana," Jurnal Penanggulangan Bencana 3, no. 1 (2012): 25-34.

11 Ali M and Ismaila Rimi Abu bakar AlQahtany, "Public Perception and Attitudes to Disaster Risks in a Coastal Metropolis of Saudi Arabia," International Journal of Disaster Risk Reduction 44 (2020): 89-93.

12 Otto Soemarwoto, Ekologi Lingkungan Hidup Dan Pembangunan (Jakarta: Djambatan, 1983).

13 Ibid.

14 NHT Siahaan, Hukum Lingkungan, 1st ed. (Jakarta: Pancuran Alam, 2006).

15 Andi Yaqub, "Fikih Lingkungan Dalam Peta Pembangunan Nasional," Jurnal Bilancia IAIN Palu 11, no. 1 (2017): 1-32. 
solution to an environmental crisis ${ }^{16}$. The statement was based on a historical portrait when looking at the development of religions in various parts of the world but was unable to put a halt to the destruction of the environment. The ideal gap and reality cannot be deterred to find a more functional solution.

Currently, the Earth is undergoing a process towards something better. The process of going to something good is called the process of Transformation towards the balance of the Earth. If we analogize, something created by humans must have parts, call it motorized or electronic vehicles to repair it so that it can be used for a long time.

Likewise, God created the universe, surely this Nature was given the ability to be able to survive in any condition as well as our earth. However, in the process, the biggest obstacle is mostly due to humanity itself. If we look at God's creation we will find extraordinary beauty. A beauty and majesty that shows the majesty of the Essence that created it. The order, harmony, and beauty of the universe show that there is an Almighty and All-Wise Essence. The sky with all its decoration. Earth with oceans and rivers flowing in it. The mountains are so sturdy that they rise high. Animals and plants with various types. Everything was created so beautifully. Thinking and tadabbur towards Allah's creation will add our faith in Allah ta'ala. That is why Allah ta'la calls on humans to always contemplate His creations Allah SWT Said:

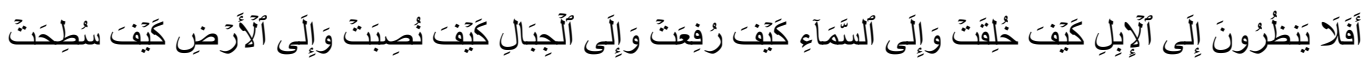

Meaning:

"Then do they not consider the camel how it was created? "And the sky, how was it raised? "And the mountains how it was erected? "And the earth how it was spread out?" (Qs. Al Ghosyihah : 17-20)

Allah ta'ala also praised Ulul Albab (intelligent person) and explained their habit of mentadaburi verses Allah ta'ala in the form of His creation. Allah Ta'ala says:

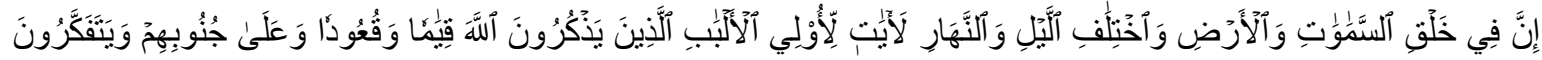

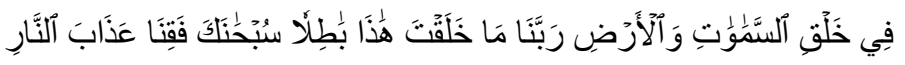

Meaning:

"Verily in the creation of the heavens and the earth, and the alternation of night and day there are signs for intelligent people "(ie) those who remember Allah while standing or sitting or lying down and they think about the creation of heaven and earth (while saying): "O our Lord, Thou hast not created this in vain, Blessed be Thou, then protect us from the torments of hell" (Qs. Al Imron : 190-191)

16 Agama Tucker, Mary Evelyn and John A. Grim, Filsafat Dan Lingkungan (Yogyakarta: Kanisius, 2007). 
Islam is one of the religions that implements its relationship with the environment, the Koran as the main guide for the religious diversity of Muslims clearly describes it. According to Nomanul Haq that the Koran talks about three simultaneous levels: metaphysical, naturalistic and human. ${ }^{17}$ This means that there is no ontological separation between revelation and nature, in human psychological instincts, all this moves people to behave towards their environment by not denying anthropocentrism. ${ }^{18}$

What about the residents of Palu, Sigi, and Donggala who experienced the direct impact of the damage? Can it be said that the residents of PASIGALA have committed acts and great sins? Of course, it can't be said that way. The disasters that occur in the Palu, Sigi, and Donggala regions are the accumulation of human error throughout the earth's surface, as Global Warming is the main cause is developed countries but developing countries which then receive such severe impacts.

This transformation process should not be seen as a disaster but rather a chance for Humans to improve themselves. Improving ourselves should not be interpreted only as religious services but also reflected in our attitude towards others, because if we think of the presence of disaster solely because of the Azab then questions will arise relating to God's justice and assume God does not have the nature of love and affection.

The Qur'an emphasizes the significance of transcendence ${ }^{19}$ from nature, because nature cannot explain events by itself. Nature is the language of the Qur'an as a sign that there is something outside of himself, which points to an entitlement transcendent. Nature is a symbol of God, which means that God speaks to humans through nature. Humans must maintain the existence of nature as one of the main impulses and sources in carrying out worship. If someone contemplates the way the Qur'an explains the creation of nature, according to Nomanul Haq, there are at least three perspectives of natural characteristics: First, that natural phenomena have regularity, a coherent and elegant balance. Second, nature does not have a guarantee to exist by

17 Kementerian Agama Indonesia, Metaphysics Is the Philosophy of Everything That Exists Outside of Nature (Jakarta: Kementerian Agama Republik Indonesia, 2008).

18 Otto Soemarwoto, Atur Diri Sendiri: Paradigma Baru Pengelolaan Lingkungan Hidup (Yogyakarta: UGM Press, 2004).

19 Kementerian Agama Indonesia, Transcendental Is to Highlight Things That Are Spiritual; Sukardi Understand; Supernatural (Jakarta: Kementerian Agama Republik Indonesia, 2008). 
itself, and nature is an embodiment of God's love or in other words, God's love is manifested in the creation of nature. ${ }^{20}$

Ideally, humans treat nature wisely so that nature is in harmony to meet everything that is human needs. Allah SWT. has given the freedom to humans to utilize in accordance with the carrying capacity of the environment by not forcing excessive desires that can result in the decadence of the quality and quantity of the environment.

The environment is very dependent on human morality and in carrying out the mandate as the caliph of Allah SWT makes it easy to subdue nature, says Allah SWT. in Q.S. al-Jasiyah 45: $12-13$

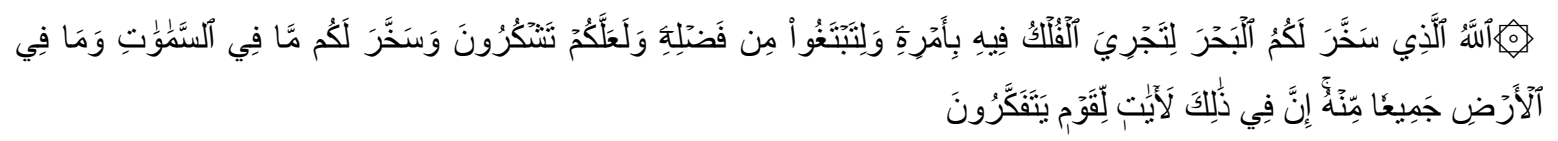

Meaning:

It is Allah Who subdues the sea for you so that ships can sail to him with His permission and so that you can seek His gifts and Hopefully you are grateful. And he has subjected to you all that is in the heavens and all that is on earth, (as a mercy) than Him. Surely in that there really are signs (the power of God) for people who think. ${ }^{21}$

M. Quraish Shihab's interpretation of the verse that the submission of heaven and earth is understood as a system, not only as an object of exploitation but Allah SWT. set it to inspire people about natural phenomena that they can use for the benefit and comfort of human life. Submission of heaven and earth for humans to submit to the creator, not to the creator. ${ }^{22}$ Although the verse is more anthropocentric (human as the ruler of the earth), but there is an order to managing it with all responsibility or the concept of the caliph referred to in Surah Al-Baqarah verse 30 meaningful responsibility.

The meaning as God's representative on earth will only apply if humans can preserve the environment so that all worship and social charity can be fulfilled properly. The breaking up of humans on earth also brings a negative impact on the balance of nature. This happens whether realized or not by humans, because their activities are dominated to take maximum benefit without taking into account the damage caused. The Qur'an has explained the terms related to environmental damage. The Word of Allah in Q.S. Al-Rum/30: 41.

\footnotetext{
20 S. Normanul Haq, "Religion and Environmental Conservation, Religion and Environmental Conservation," MI (2008): 1020.

21 Indonesia, Transcendental Is to Highlight Things That Are Spiritual; Sukardi Understand; Supernatural.

22 M. Quraish Shihab, Tafsir Al-Mishbah Vol.13 (Bandung: Lentera Hati, 2017).
} 


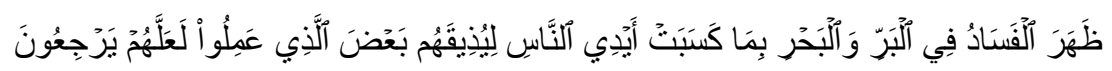

Meaning:

It has been seen that damage on land and at sea is caused by the deeds of human hands so that God will give them some of their actions so that they return (to the right path).

This is what is meant by theological awareness of the earth, an awareness that has a future and cross-world reach. This awareness can arise when humans can understand macro $\operatorname{cosmically}^{23}$ earth and life, not only the present or future, but also the period after this life. But it is still inadequate, there needs to be another approach that is more powerful.

\subsection{The Environmental Law as a Solution}

The meaning of environmental justice can be seen from the ethical view of biocentrism put forward by Sonny Keraf, namely that humans can only live and develop as whole people not only in the social community but also in the ecological community, namely beings whose lives depend on and are closely related to all another life in the universe. In other words, humans as social beings will not be separated in their role as ecological creatures. Human life is not only determined by the social community, but also the ecological community, which is a creature whose life depends on and is closely related to all other life in the universe.

Long before the natural disasters that occurred in the Central Sulawesi region Especially in the city of Palu, Sigi, and Donggala, environmental issues were one of the world's most pressing problems at the end of this decade, including in Indonesia, especially in Central Sulawesi. Environmental and disaster studies have always been very interesting. discussed because it involves several scientific disciplines be it political, economic, social, legal, cultural and even religious so that the solution to the problem cannot be seen only from a scientific angle but with an interdisciplinary approach.

Cases related to disaster mapping are still many errors and of course returning to the affected communities, as happened on September 28, 2018, where the Government through BMKG issued a status of alert related to the earthquake disaster that was announced as having a potential tsunami then revoked the announcement and re-released that the disaster in The city of Palu became 7.4 Magnitude after previously announcing the earthquake shock of 9.0 Magnitude

23 Kementerian Pendidikan Nasional Indonesia, Cosmic Macros Namely a Comprehensive Understanding of the Universe, n.d. 
and the fact at that time the City of Palu had received a tsunami threat along with the earthquake and liquefaction.

This error then continued where misinformation occurred several times, which said that the Mamasa regency in South Sulawesi, which was a green zone, was shaken by an earthquake shortly after the disaster in Central Sulawesi. predictable parties who are declared experts in their fields, this proves to us that what is reported and announced by those who are competent in the field of the disaster called BMKG is only a visualization that has not been fully trusted because it is only a prediction and not infrequently even unpredictable.

After the disaster happened in Palu City, Sigi, and Donggala, the government established a livable zone and a non-livable zone. The red or unsuitable area in the future will be used as a green open area. A policy that is considered very good to provide security for its citizens. but the question then is whether it is right? Is it true that the red zone is dangerous? And what if it turns out that the zone that is considered red has now become a safe zone? Whereas landowners in the red zone have been moved. What are the rights to land related to the abandoned land?

The study needs to be done that really can provide certainty for the community so that people do not necessarily move without getting certainty of their rights and even relinquish their rights to their land in vain, as the theories above describe that the earth can make improvements to itself by balancing the self. In human history and those that are enshrined in the scriptures, there are no disasters that occur repeatedly in the same place, the right step is to erase the zones that have been made as a reference to liveable areas or not because it has violated the principle of the balance of the earth alone.

The law is present to provide balance and balance is an inseparable part of justice which is the purpose of the law itself. Determination of the red zone in the view of the law is a wrong thing, because with the determination as if the city of Palu since ancient times is a fault area and some opinions say ancient rivers, it will invoke perceptions related to the lack of justice of Allah SWT, which in the Quran Surah Al-Mulk Verse 3 Allah says:

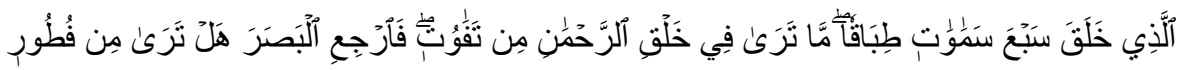

Meaning:

Who created the seven heavens in layers. You never look at the creation of God, the Most Gracious, of something out of balance. Then look again and again, do you see anything that is out of balance? 
This verse is generally only interpreted that the universe with all its contents is created in a balanced meaning, there are men and there are women, there are day and night, but if we examine deeply then we will find the meaning where the verse provides the basis that since thousands of years Religion has explained the theory of balance with the principles of ecology by making the earth a large ecosystem. The surface of the earth has been designed by Allah SWT in such a way with a level of balance to support living systems, so wherever the surface of the earth supports each other living systems, including in the city of Palu, which has been said to be a red zone. Especially in a law study based on environmental, the earth is said to be a supporter of human life as a large ecosystem, what needs to be done is to do certain research to say that the land in the cities of Palu, Sigi and Donggala has experienced a decline in quality as a Life Support System which until now could not be proven by a geologic expert, as for the presentation from those who said the geologist was visualization and imagination which then said that the earthquake occurred because of plate movements. This then makes no sense anymore because if it is said to occur in the movement of the plates, technology such as satellites that can read the contents of the earth's contents can see the movements of these plates.

The entire universe (including humans) is seen as a machine that works mechanically and can be analyzed and predicted freely regardless of the whole that formed it. The reality of the universe is also reduced from one particular aspect without seeing a more comprehensive and holistic relationship between the various aspects. ${ }^{24}$

In contrast to geologists, if departing on the principles of environmental law and the Word of Allah SWT then it can be said that an earthquake is not a disaster but is a process of adaptation of the earth's surface to the earth's core due to a decrease in quality so that after the earthquake that occurred in Palu then the surface quality can be ascertained the earth is much better than before, which is why no area experiencing a great shock will experience the same shock a second time.

So there is no need to establish a red zone for the area in the city of Palu, Sigi Regency and Donggala Regency especially in the city of Palu in the area, Palu Bay, Balaroa and Petobo when compared to the Jakarta bay where reclamation is carried out which then allows humans to build facilities and infrastructure on it, what else only a land like Petobo and Balaroa. So that the citizens do not lose their rights to their land and can reside in their area again because by setting the red zone is the same as denying the power of God Almighty Allah SWT.

24 Akib Muhammad, "Pergeseran Paradigma Penegakan Hukum Lingkungan: Dari Mekanistik-Reduksionis Ke Holistik-Ekologi,” Masalah Masalah Hukum 43, no. 1 (2014): 125-134. 
Comparative nalysis can be carried out to formulate the general parts of the behavior patterns of individuals and their social units, ranging from family, an organization to the community. ${ }^{25}$ Develop ingredients that give focus on the social dimension of disaster, a number of post-disaster study results, preparedness and mitigation, causes of disasters, as well a number of post-disaster assessments, including studies about disaster preparedness. ${ }^{26} \mathrm{~A}$ disaster event is characterized by damage to social and economic patterns normal community existed before. ${ }^{27}$ It also shows that crises equal disasters and disasters from a sociological perspective are events beyond all social crisis events that cause maximum community damage and dislocation.

Lately, there has been growing concern about the role of local knowledge in disaster risk reduction efforts ${ }^{28}$ Mercer defines local knowledge as a set of knowledge that is believed and believed by the local community within a certain period through the accumulation of experiences, community relations with nature, practices and community institutions that are passed on between generations ${ }^{29}$

There still needs to be a horizontal organization of zoning issues for sustainable development in PASIGALA. The essence of horizontal organizing is an interaction that is based on the same freedom and responsibility without elements of control, order, and outside domination. Jack Zwemer states that in real human life, control over choices and behavior must not come from the outside because external controls are not effective in damaging important human functions as a personally responsible entity. ${ }^{30}$ From various analyzes of disaster events, viewed from the perspective of environmental law, it provides proposals in disaster management, as stated by Thomas Drabek ${ }^{31}$ Some important principles and recommendations given include: (1) In all disaster events, it is important to understand how the pattern of individual or community knowledge of a disaster threat and how they deal with the threat; (2) Disaster

25 Gary A Kreps, “Sociological Inquiry and Disaster Research,” Annual Review of Sociology 10 (1984): 309-330.

26 Thomas E and David A. McEntire Drabek, "Emergent Phenomena and Multiorganizational Oordination in Disasters: Lessons from the Research Literature," International Journal of Mass mergencies and Disasters 20 (2002): 197-224.

27 Neal Britton, “Organized Behavior in Disaster: A Review Essay," International Journal of Mass Emergencies and Disasters (1988): 363-395.

28 S.J [et.al] Cronin, "Participatory Methods of Incorporating Scientific with Traditional Knowledge for Volcanic Hazard Management on Ambae Island, Vanuatu," Bulletin of Volcanology (2004): 652-668.

29 P Sillitoe, "Let Them Eat Cake: Indigenous Knowledge, Science and the Poorest of the Poor," Anthropology Today (2000): 3-17.

30 Jack Zwemer, "The Nature of the Human Self," Journal Quest Glendale 7 (2004): 11-32.

31 Thomas E and David A. McEntirev Drabek, "Emergent Phenomena and the Sociology of Disaster: Lessons, Trends and Opportunities from the Research Literature," Disaster Prevention and Management Review 12 (2003): 97-112. 
planning and preparedness activities are ongoing learning processes, not end goals; ${ }^{32}$ (3) it is very inappropriate if the zoning determination is carried out in the PASIGALA region because with the zoning system it makes it look as if the learning of disaster mitigation has been completed. What needs to be considered is that environmental law related to natural resource rights, namely regarding ownership of land that is given zoning, must be considered by the government; (4) The environmental law perspective is not just knowledge, but should be a guide in developing program activities, priorities, and strategies for implementing sustainable management plans $^{33}$ (5) If a disaster management strategy is needed to be a reference in responding to human or group behaviors in dealing with disasters effectively, it should be developed and applied to be part of everyday people's lives or groups ${ }^{34}$, associated with PASIGALA conditions, it is necessary to consider that in fact, all places in the Palu Koro region are disaster-prone, the zoning is not yet appropriate, the strategy that should be done is to provide disaster mitigation knowledge to the community; (6) Management of emergency response requires the implementation of a theoretical model based on local resources when compared with decisions based on local authorities, ${ }^{35}$ by him, the determination of the red zone and the disaster zone of land owned by citizens must still consider the replacement of its citizens.

\section{Conclusions}

The law exists to state that it is not true that the City of Palu, Sigi and Donggala will not be inhabited forever, the establishment of the red zone must be removed because it is not an appropriate solution and the status of the people's land does not need to change. There must not be a statement which then states that Palu is a fault area so the Palu valley in particular and the Sigi Regency and Donggala Regency are uninhabitable areas. The opinion of geologists regarding the condition of Palu which is a fault area is only a temporary phenomenon.

\section{References}

AlQahtany, Ali M and Ismaila Rimi Abu bakar. "Public Perception and Attitudes to Disaster

32 Russell R Dynes, "Community Emergency Planning: False Assumptions and Inappropriate Nalogies," International Journal of Mass Emergencies and Disasters 12 (1994): 141-158.

33 David M and Brenda D. Phillips Neal, "Effective Emergency Management: Reconsidering the Bureaucratic Approach," Disasters: The Journal of Disaster Studies, Policy and Management 19 (1995): 327-337.

34 Rudy Pramono, "Perspektif Sosiologis Dalam Penanggulangan Bencana," Jurnal Masyarakat \& Budaya 18 (2016): 81-96.

35 Russell R and Thomas E. Drabek Dynes, "The Structure of Disaster Research: Its Policy and Isciplinary Implications," International Journal of Mass Emergencies and Disasters 12 (1994): 5-23. 
Risks in a Coastal Metropolis of Saudi Arabia." International Journal of Disaster Risk Reduction 44 (2020): 89-93.

BNPB Provinsi Sulawesi Tengah. “Gempa Dan Tsunami Palu Merusak 66926 Rumah.” Tempo.

_. "Kerusakan Akibat Gempa Palu Di Wilayah Petobo.” BNPB Provinsi Sulawesi Tengah.

Britton, Neal. “Organized Behavior in Disaster: A Review Essay.” International Journal of Mass Emergencies and Disasters (1988): 363-395.

CNN Indonesia. "Peneliti: Palu Langganan Bencana Tak Layak Jadi Kota." CNN Indonesia. Jakarta, November 2019.

Cronin, S.J [et.al]. "Participatory Methods of Incorporating Scientific with Traditional Knowledge for Volcanic Hazard Management on Ambae Island, Vanuatu." Bulletin of Volcanology (2004): 652-668.

Drabek, Thomas E and David A. McEntire. "Emergent Phenomena and Multiorganizational Oordination in Disasters: Lessons from the Research Literature.” International Journal of Mass mergencies and Disasters 20 (2002): 197-224.

Drabek, Thomas E and David A. McEntirev. "Emergent Phenomena and the Sociology of Disaster: Lessons, Trends and Opportunities from the Research Literature.” Disaster Prevention and Management Review 12 (2003): 97-112.

Dynes, Russell R. "Community Emergency Planning: False Assumptions and Inappropriate Nalogies." International Journal of Mass Emergencies and Disasters 12 (1994): 141-158.

Dynes, Russell R and Thomas E. Drabek. "The Structure of Disaster Research: Its Policy and Isciplinary Implications." International Journal of Mass Emergencies and Disasters 12 (1994): 5-23.

Haq, S. Normanul. "Religion and Environmental Conservation, Religion and Environmental Conservation." MI (2008): 1020.

Indonesia, Kementerian Agama. Metaphysics Is the Philosophy of Everything That Exists Outside of Nature. Jakarta: Kementerian Agama Republik Indonesia, 2008.

- Transcendental Is to Highlight Things That Are Spiritual; Sukardi Understand; Supernatural. Jakarta: Kementerian Agama Republik Indonesia, 2008.

Indonesia, Kementerian Pendidikan Nasional. Cosmic Macros Namely a Comprehensive Understanding of the Universe, n.d.

Kreps, Gary A. "Sociological Inquiry and Disaster Research.” Annual Review of Sociology 10 (1984): 309-330. 
Mahoro, Jean Claude Geofrey. “ICAO'S Role In Environmental Protection And Its Shortcomings Under Rapid Growth Of Aviation Industry.” Diponegoro Law Review 4, no. 2 (2019): 3-15.

Mareta, Nandian. Disaster Knowledge and Management NMST. Jakarta: LIPI, 2014.

Muhammad, Akib. "Pergeseran Paradigma Penegakan Hukum Lingkungan: Dari MekanistikReduksionis Ke Holistik-Ekologi.” Masalah Masalah Hukum 43, no. 1 (2014): 125-134.

Neal, David M and Brenda D. Phillips. "Effective Emergency Management: Reconsidering the Bureaucratic Approach." Disasters: The Journal of Disaster Studies, Policy and Management 19 (1995): 327-337.

Norton, John and Terry David Gibson. "Introduction to Disaster Prevention: Doing It Differently by Rethinking Thenature of Knowledge and Learning." Disaster Prevention and Management (2019): 47-60.

Pramono, Rudy. "Perspektif Sosiologis Dalam Penanggulangan Bencana.” Jurnal Masyarakat \& Budaya 18 (2016): 81-96.

Pramoto, Rahmat Aris ; Iwan Rudiarto. "Tsunami Modeling and Its Implications for Disaster Mitigation in Palu City." Jurnal Pembangunan Wlayah dan Kota, Biro Penerbit Planologi Undip (2013): 37-49.

Shihab, M. Quraish. Tafsir Al-Mishbah Vol.13. Bandung: Lentera Hati, 2017.

Siahaan, NHT. Hukum Lingkungan. 1st ed. Jakarta: Pancuran Alam, 2006.

Sillitoe, P. "Let Them Eat Cake: Indigenous Knowledge, Science and the Poorest of the Poor." Anthropology Today (2000): 3-17.

Soemarwoto, Otto. Atur Diri Sendiri: Paradigma Baru Pengelolaan Lingkungan Hidup. Yogyakarta: UGM Press, 2004.

—. Ekologi Lingkungan Hidup Dan Pembangunan. Jakarta: Djambatan, 1983.

Sulistyaningsih, Wiwik. "Ketangguhan Mental Anak Dalam Menghadapi Bencana." Jurnal Penanggulangan Bencana 3, no. 1 (2012): 25-34.

Tucker, Mary Evelyn and John A. Grim, Agama. Filsafat Dan Lingkungan. Yogyakarta: Kanisius, 2007.

Yaqub, Andi. "Fikih Lingkungan Dalam Peta Pembangunan Nasional." Jurnal Bilancia IAIN Palu 11, no. 1 (2017): 1-32.

Zwemer, Jack. “The Nature of the Human Self.” Journal Quest Glendale 7 (2004): 11-32. 